\title{
THE CORRELATION BETWEEN THE ALBUMIN AND ALPHA GLOBULIN CONTENTS OF PLASMA ${ }^{1}$
}

\author{
By BACON F. CHOW \\ (From the Division of Protein Chemistry, The Squibb Institute For Medical Research, \\ New Brunswick, N.J.)
}

(Received for publication January 28, 1947)

The hypoalbuminemia which accompanies insufficient protein intake has come to be generally accepted as a diagnostic sign of protein deficiency (1). Experimental study of dogs depleted in protein by low protein diet feeding, manifests the same marked decrease in the plasma albumin, but not in the plasma globulin (2). Further study has shown this condition to be also characterized by an increase in the concentration of alpha globulins $(3,4)$. This loss of albumin, if expressed as total protein in circulation, becomes more apparent, since protein depletion is commonly accompanied by a decrease in plasma volume $(4,5)$. On the other hand, the total circulating alpha globulins remain essentially constant and other globulins decrease slightly. It would seem possible from these considerations that the decrease in the concentration of albumin and the increase in the concentration of alpha globulins might together furnish an index of the degree of protein depletion more valuable than that obtained from the albumin alone.

Were such a relationship to hold for man, as it would appear to hold for dogs under experimental conditions, then it would permit the utilization of the ratio of the two moieties of plasma protein as a measure of depletion.

The possibility has been examined by determining the concentration of plasma albumin and alpha globulins in the plasma of a number of patients with several types of diseases and with different levels of plasma protein concentration. The estimations were based upon data derived from electrophoretic patterns of plasma. A limited number of patients were also studied before, during, and after the administration of several protein hydrolysates to ascertain whether an increase of the percentage of plasma albumin is accompanied by a reciprocal change in the plasma alpha globulins. The results of these studies are the subject of this communication.

\section{EXPERIMENTAL}

Twenty ml. of blood from each patient under investigation were introduced into a centrifuge tube containing solid sodium oxalate as anti-coagulant. After centrifugation about $8 \mathrm{ml}$. of the plasma were diluted with an equal volume of diethylbarbiturate buffer of $\mathrm{pH}=8.4$ and ionic strength of 0.10 and then dialyzed against the same buffer for 24 hours or longer. After adequate dialysis the bag was opened and the solution was electrolyzed according to the technic of Longsworth (6). The electrolysis was carried out for a sufficient length of time (3 hours) to permit a clear-cut separation of alpha globulins from the albumin. The total plasma protein concentrations were determined by micro Kjeldahl.

\section{RESULTS}

One hundred ninety-eight samples of plasma taken from patients with several diseases were analyzed. The results are illustrated in Figure 1, in which per cent of plasma albumin is plotted against per cent of alpha globulins and a curve is fitted to the data. The distribution of the data about the mean is reasonably normal as indicated by the lines in the figure demonstrating the areas of 1 and 2 standard deviations. A correlation co-

1 The author is indebted to Shirley DeBiase for her technical assistance in electrophoretic analyses.

TABLE I

The correlation between per cents of albumin and alpha globulins

\begin{tabular}{|c|c|c|c|c|c|c|c|c|c|}
\hline \multirow{2}{*}{$\underset{\text { min }}{\text { mer cent }}$} & \multicolumn{9}{|c|}{$\begin{array}{l}\text { Alpha globulins } \\
\text { per cent }\end{array}$} \\
\hline & $5-10$ & $10-15$ & $15-20$ & 20-25 & $25-30$ & $30-35$ & $35-40$ & $40-45$ & $45-50$ \\
\hline $\begin{array}{l}70-75 \\
65-70 \\
60-65 \\
55-60 \\
50-55 \\
45-50 \\
40-45 \\
35-40 \\
30-35 \\
25-30 \\
20-25\end{array}$ & $\begin{array}{l}1 \\
4 \\
2 \\
3 \\
6 \\
2 \\
1 \\
0 \\
0 \\
0 \\
0\end{array}$ & $\begin{array}{r}0 \\
6 \\
5 \\
8 \\
\mathbf{8} \\
11 \\
2 \\
3 \\
\mathbf{0} \\
0 \\
0 \\
0\end{array}$ & $\begin{array}{r}0 \\
2 \\
5 \\
12 \\
11 \\
17 \\
6 \\
7 \\
0 \\
0 \\
0\end{array}$ & $\begin{array}{r}0 \\
0 \\
0 \\
1 \\
6 \\
12 \\
15 \\
7 \\
4 \\
2 \\
0\end{array}$ & $\begin{array}{r}0 \\
0 \\
0 \\
0 \\
0 \\
5 \\
14 \\
1 \\
2 \\
2 \\
1 \\
\end{array}$ & $\begin{array}{l}0 \\
0 \\
0 \\
0 \\
0 \\
0 \\
2 \\
2 \\
2 \\
1 \\
1\end{array}$ & $\begin{array}{l}\mathbf{0} \\
\mathbf{0} \\
\mathbf{0} \\
\mathbf{0} \\
\mathbf{0} \\
\mathbf{0} \\
\mathbf{0} \\
\mathbf{0} \\
\mathbf{0} \\
\mathbf{0} \\
1\end{array}$ & $\begin{array}{l}0 \\
0 \\
0 \\
0 \\
0 \\
0 \\
0 \\
0 \\
0 \\
0 \\
1\end{array}$ & $\begin{array}{l}0 \\
0 \\
0 \\
0 \\
0 \\
0 \\
0 \\
0 \\
0 \\
1 \\
1 \\
\end{array}$ \\
\hline Total & 19 & 35 & 60 & 47 & 25 & 8 & 1 & 1 & 2 \\
\hline
\end{tabular}




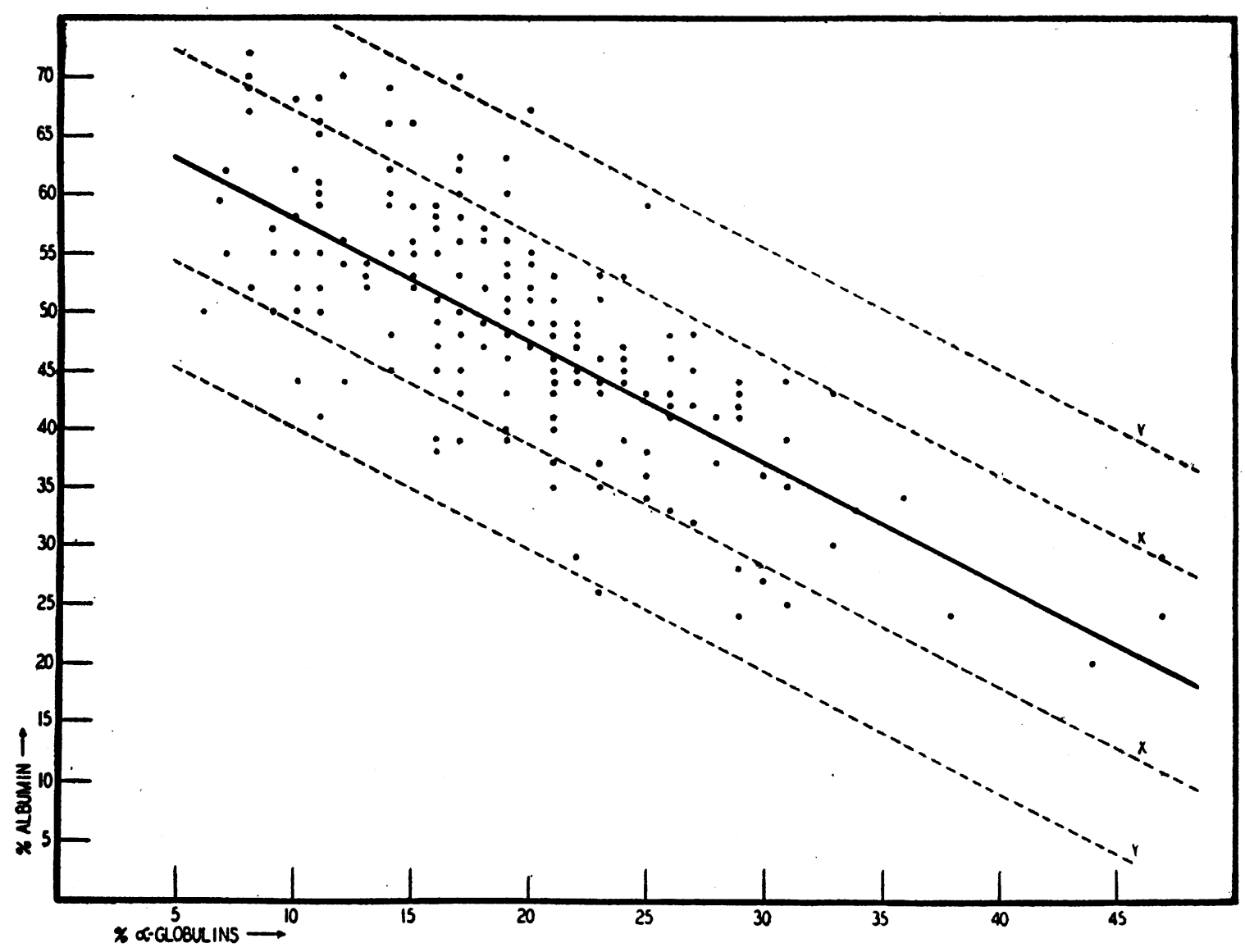

Fig. 1. The Relationship between the Percentages of Albumin and Alpha Globulins

efficient (7) of -0.63 with a standard error of \pm 0.04 was also obtained by arranging the data according to the albumin levels grouped at intervals 5 per cent apart (Table I). A negative correlation coefficient of 0.4 or greater is commonly considered statistically significant; consequently the results demonstrate an inverse relationship between the concentrations of albumin and alpha globulins. However, the correlation is not sufficiently close to provide useful information when one considers a single sample of serum.

A similar attempt was made to establish a correlation between the per cent albumin and total plasma protein concentration. However, the data reveal no relationship with statistical significance. Twenty-five samples with total protein concentrations of 6.5 grams per cent or even higher, have albumin levels between 30 per cent and 40 per cent. At the same time, 33 samples of plasma with a protein concentration of 6.5 grams per cent or less have protein concentrations as high as 50 per cent or above. Thus, there appears to be no relationship between per cent albumin and plasma protein concentration. Unfortunately the plasma volumes of these patients are not available.

A casein hydrolysate ${ }^{2}$ or other commercially available hydrolysates (at a dose of about 5 to 6 grams per kilogram body weight per day) were administered orally to 11 patients for several weeks. The first 8 patients (column I, Table II) were hypoalbuminemic. The 9th patient (Urban) had low protein concentration ( 4.8 gram per cent) but normal albumin content before treatment. The remaining 2 patients (Migut and $\mathrm{Kjaer}$ ) had normal plasma protein concentration and normal albumin content.

The data do not constitute a comparison of the relative effectiveness of the various hydrolysates

2 The casein hydrolysate was supplied by E. R. Squibb \& Sons. 
used. However, they do demonstrate that the administration of an adequate protein hydrolysate brings about plasma albumin regeneration despite differences in the state of hypoproteinemia. As is to be expected, this is most marked where the hypoalbuminemia is severe. Also, the increase of per cent of albumin is accompanied by a drop in alpha globulins. It is interesting to note that the albumin content of Summelensky was 39 per cent before treatment, was increased to 65 per cent after 3 weeks of treatment, but dropped to 43 per cent after 8 weeks of treatment. During the corresponding periods, the per cent of alpha globulins dropped when the alburmin increased and increased when the albumin decreased.

The relationships between the concentrations of plasma albumin and alpha globulins in the second samples from these 11 patients were plotted in the same manner as the random samples in

TABLE II

The effect of administration of protein hydrolysate to hypoalbuminemic patients

\begin{tabular}{|c|c|c|c|c|c|c|c|c|c|}
\hline \multirow{2}{*}{ Name } & \multirow{2}{*}{$\begin{array}{c}\text { Hydro- } \\
\text { lysate } \\
\text { given }\end{array}$} & \multirow{2}{*}{$\begin{array}{l}\text { Protein } \\
\text { concen- } \\
\text { tration } \\
\text { gram } \\
\text { per cent }\end{array}$} & \multicolumn{6}{|c|}{ Composition in per cent } & \multirow{2}{*}{$\begin{array}{l}\text { Weeks } \\
\text { of } \\
\text { admin- } \\
\text { istra- } \\
\text { tion }\end{array}$} \\
\hline & & & 1 & 2 & 3 & 4 & 5 & 6 & \\
\hline Young & Squibb'1 & $\begin{array}{l}4.62 \\
6.52\end{array}$ & $\begin{array}{l}20 \\
37 \\
40\end{array}$ & $\begin{array}{r}13 \\
9 \\
8\end{array}$ & $\begin{array}{l}31 \\
13 \\
11\end{array}$ & $\begin{array}{l}12 \\
16 \\
17\end{array}$ & $\begin{array}{l}12 \\
10 \\
11\end{array}$ & $\begin{array}{l}12 \\
15 \\
13\end{array}$ & $\begin{array}{l}\mathbf{0} \\
\mathbf{2} \\
\mathbf{3}\end{array}$ \\
\hline Egan & Amigen 1 & $\begin{array}{l}7.40 \\
7.68\end{array}$ & $\begin{array}{l}26 \\
40\end{array}$ & $\begin{array}{l}8 \\
6\end{array}$ & $\begin{array}{l}15 \\
13\end{array}$ & $\begin{array}{l}7 \\
9\end{array}$ & $\begin{array}{l}6 \\
5\end{array}$ & $\begin{array}{l}38 \\
27\end{array}$ & $\begin{array}{l}0 \\
4\end{array}$ \\
\hline Porter & Squibb & $\begin{array}{l}\mathbf{5 . 8 9} \\
\mathbf{8 . 0} \\
\mathbf{8 . 5}\end{array}$ & $\begin{array}{l}32 \\
45 \\
50\end{array}$ & $\begin{array}{l}9 \\
4 \\
4\end{array}$ & $\begin{array}{r}18 \\
13 \\
2\end{array}$ & $\begin{array}{r}12 \\
9 \\
10\end{array}$ & $\begin{array}{r}4 \\
4 \\
13\end{array}$ & $\begin{array}{l}25 \\
25 \\
21\end{array}$ & $\mathbf{0}$ \\
\hline Lopez & Amigen & $\begin{array}{l}6.76 \\
6.40\end{array}$ & $\begin{array}{l}33 \\
52\end{array}$ & $\begin{array}{l}7 \\
7\end{array}$ & $\begin{array}{r}19 \\
6\end{array}$ & $\begin{array}{r}17 \\
9\end{array}$ & 10 & $\begin{array}{l}20 \\
16\end{array}$ & $\begin{array}{l}0 \\
6\end{array}$ \\
\hline Gates & Essamine & $\begin{array}{l}5.99 \\
5.66\end{array}$ & $\begin{array}{l}35 \\
51\end{array}$ & $\begin{array}{l}9 \\
8\end{array}$ & $\begin{array}{l}14 \\
12\end{array}$ & $\begin{array}{r}7 \\
12\end{array}$ & $\begin{array}{r}13 \\
5\end{array}$ & $\begin{array}{l}22 \\
12\end{array}$ & $\begin{array}{l}0 \\
6\end{array}$ \\
\hline Summelensky & Squibb & $\begin{array}{l}6.02 \\
5.21 \\
6.01\end{array}$ & $\begin{array}{l}39 \\
65 \\
43\end{array}$ & $\begin{array}{r}9 \\
6 \\
10\end{array}$ & $\begin{array}{r}15 \\
5 \\
19\end{array}$ & $\begin{array}{r}10 \\
9 \\
14\end{array}$ & $\begin{array}{l}7 \\
7 \\
1\end{array}$ & $\begin{array}{r}20 \\
8 \\
13\end{array}$ & $\begin{array}{l}\mathbf{0} \\
\mathbf{3} \\
\mathbf{8}\end{array}$ \\
\hline Zacharchuk & Edamin? & $\begin{array}{l}6.36 \\
6.02\end{array}$ & $\begin{array}{l}41 \\
56\end{array}$ & $\begin{array}{r}15 \\
5\end{array}$ & $\begin{array}{l}11 \\
10\end{array}$ & $\begin{array}{r}14 \\
9\end{array}$ & $\begin{array}{l}4 \\
3\end{array}$ & $\begin{array}{l}15 \\
17\end{array}$ & $\begin{array}{l}0 \\
4\end{array}$ \\
\hline Davis & Squibb & $\begin{array}{l}5.36 \\
7.01\end{array}$ & $\begin{array}{l}43 \\
56\end{array}$ & $\begin{array}{r}10 \\
5\end{array}$ & $\begin{array}{l}15 \\
12\end{array}$ & $\begin{array}{r}12 \\
7\end{array}$ & 4 & $\begin{array}{l}16 \\
16\end{array}$ & $\begin{array}{l}0 \\
4\end{array}$ \\
\hline Urban & Squibb & $\begin{array}{l}4.84 \\
6.07\end{array}$ & $\begin{array}{l}55 \\
57\end{array}$ & $\begin{array}{r}11 \\
9\end{array}$ & 4 & $\begin{array}{l}15 \\
12\end{array}$ & $\begin{array}{l}8 \\
7\end{array}$ & $\begin{array}{l}7 \\
8\end{array}$ & $\begin{array}{l}\mathbf{0} \\
\mathbf{3}\end{array}$ \\
\hline Migut & Squibb & $\begin{array}{l}\mathbf{8 . 0 0} \\
\mathbf{8 . 8 2}\end{array}$ & $\begin{array}{l}48 \\
52\end{array}$ & $\begin{array}{l}9 \\
6\end{array}$ & $\begin{array}{l}17 \\
15\end{array}$ & $\begin{array}{l}10 \\
10\end{array}$ & $\begin{array}{l}3 \\
5\end{array}$ & $\begin{array}{l}13 \\
12\end{array}$ & $\begin{array}{l}0 \\
6\end{array}$ \\
\hline Kjaer & Squibb & $\begin{array}{l}7.32 \\
8.00\end{array}$ & $\begin{array}{l}59 \\
72\end{array}$ & $\begin{array}{l}6 \\
2\end{array}$ & $\begin{array}{r}19 \\
6\end{array}$ & $\begin{array}{l}8 \\
2\end{array}$ & $\begin{array}{r}2 \\
12\end{array}$ & $\begin{array}{l}6 \\
6\end{array}$ & $\begin{array}{l}\mathbf{0} \\
\mathbf{1}\end{array}$ \\
\hline
\end{tabular}

1 Casein hydrolysates.

2 Lactalbumin hydrolysates.

$1=$ Albumin

2 - Alphas globulin

3 - Alphas globulin

4 - Beta globulin

$5=$ Fibrinogen

6 - Gamma globulin
Figure 1. The relationships between these two moieties at different levels of protein concentration in the individual patient were generally closer than that of the random samples shown in Figure 1. This fortifies the view that an inverse relationship between the two usually exists, but again it is to be emphasized that the ratio of the two fractions is not useful in the evaluation of the nutritional status of any single patient. The compositions of the other plasma protein components are recorded in Table II, but the effects of administration of the hydrolysates on these components are erratic and no conclusion can be drawn.

\section{DISCUSSION}

Electrophoretic analysis is a useful tool for the determination of the composition of plasma proteins. During the past few years, numerous investigations were made to correlate the change in plasma protein pattern with a specific disease. It has been found that diseases such as hyperthyroidism (8), malaria (9), pneumonia (10), streptococcus infections, relapsing fever, and scarlet fever (11) are accompanied by a rise in alpha globulins, some depression of albumin, and occasionally a rise in other globulins. These findings have usually been attributed to the disease rather than, as seems likely, the protein deficiency which is incidental to the disease.

The data presented include sera from 76 patients with peptic ulcer, 51 patients with tuberculosis, 25 patients with malnutrition, and 37 with miscellaneous conditions. These show that a lowering of albumin is generally accompanied by a rise in the alpha globulin. This increase, although statistically significant, is not sufficiently close for clinical use in the evaluation of the state of protein nutrition of the individual patient. The relationships are sufficiently similar to those observed in simple protein depletion to lead one to conclude that the alterations of normal plasma pattern are in fact due to the same fundamental mechanism, i.e., inadequate protein retention as an incidental phenomenon in each of the diseases studied. It is not surprising then that the patients with a low albumin content of the plasma are treated by the administration of an adequate protein hydrolysate, thus correcting the protein deficiency; a rise of albumin occurs quite promptly and this is accom- 
panied by a decrease in the concentration of alpha globulins.

\section{SUMMARY}

One hundred ninety-eight samples of plasma from patients with several diseases were analyzed electrophoretically. There appears to be a correlation between the decrease in albumin and the increase in the per cent of alpha globulins. The significance of this relationship with respect to diseases is discussed.

\section{BIBLIOGRAPHY}

1. Peters, J. P., Nitrogen metabolism in acute and chronic disease. Ann. N. Y. Acad. of Sci., 1946, 47, 327.

2. Weech, A. A., and Goettsch, E., Dietary protein and the regeneration of serum albumin. II. Comparison of the potency values of beef serum, beef muscle and casein. Bull. Johns Hopkins Hosp., 1938, 63, 181.

3. Zeldis, L. J., Alling, E. L., McCoord, A. B., and Kulka, J. P., Plasma protein metabolism-electrophoretic studies; chronic depletion of circulating proteins during low-protein feeding. J. Exper. Med., 1945, 82, 157.
4. Chow, B. F., Allison, J. B., Cole, W. H., and Seeley, $R$. D., Effect of protein depletion on plasma proteins in dog measured by electrophoretic analysis. Proc. Soc. Exp. Biol. \& Med., 1945, 60, 14.

5. Weech, A. A., Wallstein, M., and Goettsch, E., Nutritional edema in the dog. V. Development of deficits in erythrocytes and hemoglobin on a diet deficient in proteins. J. Clin. Invest., 1937, 16, 719.

6. Longsworth, L. G., Recent advances in the study of proteins by electrophoresis. Chem. Rev., 1942, 30, 323.

7. Croxton, F. E., and Cowden, D. J., Applied General Statistics, 1940, p. 673.

8. Lewis, L. A., and McCullagh, E. P., Electrophoretic analysis of plasma proteins in hyperthyroidism and hypothyroidism. Am. J. Med. Sci., 1944, 208, 727.

9. Dole, V. P., and Emerson, K., Jr, .Electrophoretic changes in plasma protein patterns of patients with relapsing malaria. J. Clin. Invest., 1945, 24, 644.

10. Longsworth, L. G., Shedlovsky, T., and MacInnes, D. A., Electrophoretic patterns of normal and pathological human blood serum and plasma. J. Exper. Med., 1939, 70, 399.

11. Dole, V. P., Watson, R. F., and Rothbard, S., Electrophoretic changes in serum protein patterns of patients with scarlet fever and rheumatic fever. J. Clin. Invest., 1945, 24, 648. 